\title{
Bulletin of the Seismological Society of America
}

\begin{tabular}{lll}
\hline Vol. 37 & JULY, 1947 & No. 3 \\
\hline
\end{tabular}

THE MANIX (CALIFORNIA) EARTHQUAKE OF APRIL 10, 1947*

\author{
By C. F. Richter
}

THIS REPORT presents seismometric and field data, exclusive of those relating to geology and field evidence of faulting. It includes information reaching the Seismological Laboratory at Pasadena from various sources and embodies the results of investigation by members of the Laboratory staff, and by other staff members and students of the Division of the Geological Sciences, California Institute of Technology. All times mentioned are Pacific Standard Time.

The central Mojave Desert has been a source of occasional small to moderate shocks during twenty years of instrumental registration at Pasadena and its auxiliary stations. Shocks occur near the line of the Atchison, Topeka and Santa Fe Railroad between Barstow and Ludlow; others have been located northwest, north, and northeast of Barstow.

A shock of magnitude 5.1 on September 26, 1929, at 12:00:23, was located by Gutenberg (1932) at $34^{\circ} 50^{\prime} \mathrm{N}, 116^{\circ} 31^{\prime} \mathrm{W}$. This was barely perceptible in Pasadena. Thereafter, shocks occurred in the central desert area rather frequently until 1932. After a major earthquake in Nevada on December 20, 1932, this activity practically ceased, and did not resume until 1938. Since then there has been a gradual increase in the number and magnitude of these earthquakes. On July 18, 1946, at $06: 27: 58$, a shock of magnitude 5.6 near $34^{\circ} 32^{\prime} \mathrm{N}, 115^{\circ} 59^{\prime} \mathrm{W}$, reached intensity $\mathrm{V}$ at Amboy and was felt to distances exceeding $200 \mathrm{~km}$. This was the largest of the series prior to the earthquake of April 10,1947, for which a preliminary magnitude determination is 6.8 , with an epicenter near the Mojave River, south of Manix and Field stations on the Union Pacific Railroad. The geology of the area has been studied by Buwalda (1914).

Only two earlier shocks in this vicinity have been identified, as follows:

$\begin{array}{llllc} & & \text { Lat. } N & \text { Long. W } & \text { Magnitude } \\ 1942 \text { August } 9 \ldots \ldots \ldots \ldots & 09: 47: 02 & 34^{\circ} 55^{\prime} & 116^{\circ} 35^{\prime} & 3 \\ 1945 \text { May } 27 \ldots \ldots \ldots \ldots & 05: 33: 44 & 3457 & 11629 & 2.9\end{array}$

\footnotetext{
* Manuscript received for publication May 20, 1947.
} 
Location for the first of these is less accurate than for the 1947 shocks; the data for the second agree fairly well with those of some of the later shocks of the 1947 group, with epicenters southward from that of the main earthquake. A few other shocks, rather larger and better located, have originated to the north, beyond the Union Pacific line. No true foreshock preceding the main shock of 1947 was recorded.

Times of first motion for the main shock are given in table 1. Mr. J. M. Nordquist has carried out a least-squares solution for epicenter and origin time, supposing the travel time in seconds for the first motion to be given by

TABLE 1

Distances, Travel Times, and Resmduls in Time for the Principal Manix Shock

\begin{tabular}{|c|c|c|c|}
\hline Station & $\Delta$ & Time of first motion & $\mathrm{O}-\mathrm{C}$ \\
\hline Riverside... & $\begin{array}{c}\mathrm{km} . \\
132.9\end{array}$ & $\begin{array}{ccc}\text { h. } & \text { m. } & \text { s. } \\
07 & 58 & 27.0\end{array}$ & $\begin{array}{l}\text { sec. } \\
-0.1\end{array}$ \\
\hline Mount Wilson . . . . . . . . . . . & 162.4 & 31.1 & +0.2 \\
\hline 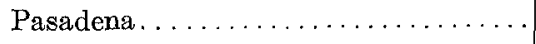 & 175.8 & 32.4 & 0.0 \\
\hline Palomar. . . . . . . . . . . . . & 181.8 & 33.6 & +0.3 \\
\hline Haiwee. . . . . . . . . . . . . . & 183.8 & 33.1 & -0.5 \\
\hline Boulder City . . . . . . . . . . . . & 190.6 & 34.3 & -0.1 \\
\hline 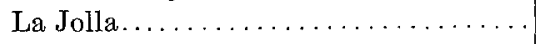 & 242.6 & 41.2 & +0.5 \\
\hline Pierce Ferry. .............. & 262.3 & 43.7 & +0.6 \\
\hline 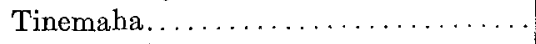 & 283.0 & 46.0 & +0.1 \\
\hline 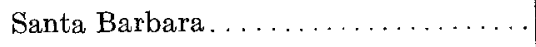 & 297.5 & 47.5 & 0.0 \\
\hline 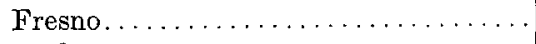 & 356.5 & 56 & $(+1.2)$ \\
\hline 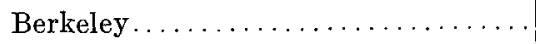 & 606.6 & 5926 & $(+0.2)$ \\
\hline Tucson................ & 608.6 & 25.6 & -0.7 \\
\hline
\end{tabular}

$\mathrm{P}_{\mathrm{n}}-\mathrm{O}=7.0+0.124 \Delta$ ( $\Delta$ being the epicentral distance in kilometers). The result gives for epicenter and origin time $34^{\circ} 58: 0 \pm 1: 5 \mathrm{~N}, 116^{\circ} 31: 8 \pm 1: 5$ $\mathrm{W}, \mathrm{O}=07: 58: 03.6 \pm 0.3$. Distances given in table 1 are calculated from this epicenter; the column headed $\mathrm{O}-\mathrm{C}$ gives the residuals of the observed arrival times with reference to those calculated from the given formula, including a correction of 0.2 seconds to allow for height, applied at Mount Wilson, Palomar, Haiwee, Boulder City, Tinemaha, and Tucson.

Times at Tucson for this and other shocks are from the original seismograms, by courtesy of the U. S. Coast and Geodetic Survey. Times at Boulder City and Pierce Ferry were kindly supplied by Mr. Frank H. Werner and Mr. J. D. Carll, of the Coast and Geodetic Survey; those for Berkeley and Fresno, by Mr. John E. Meeker. Times at Berkeley and Fresno for the main shock were given only to the second, and were not used in the least-squares solution.

The calculated epicenter is indicated on the sketch map; it is very near the surface break, which follows the fault identified by Buwalda (1914), now 
named by him the Manix fault. Since the location is unusually accurate, it is interesting to note that the shock was clearly recorded at many distant stations.

At several of the nearer stations the seismogram is complicated by a distant earthquake, probably in the region of New Zealand, with first motion recorded as follows:

\begin{tabular}{|c|c|c|}
\hline & & \\
\hline Pasadena...... & & $\begin{array}{lll}58 & 07\end{array}$ \\
\hline Mount Wilson. . & & 08 \\
\hline Riverside...... & & 09 \\
\hline Palomar..... & & 08 \\
\hline Tinemaha.... & & 16 \\
\hline Pieree Ferry.. & & 25 \\
\hline Tucson......... & & 24 \\
\hline
\end{tabular}

This motion has an entirely different character from that of the California shock, which abruptly interrupts it. The relative times of the Manix shock are confirmed by comparison with those recorded for aftershocks.

A portable seismometer was operated overnight April 10-11 near old Woman Springs, at $34^{\circ} 25$ ! 1 N, $116^{\circ} 43 ! 8$ W, by Mr. F. E. Lehner, Mr. Ralph Gilman, and Mr. B. F. Howell. The four largest aftershocks recorded there had the following times of first motion:

Old Woman Springs

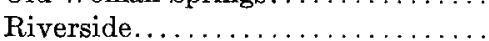

Mount Wilson...................

Pasadena.....................

Palomar.....................

Haiwee....................

Boulder City. . . . . . . . . . . . . .

Tinemaha.

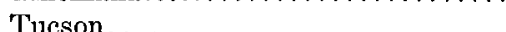

I
April 10
18:07

21.7

32.7

37.7

39.2

40.0

40.5

41.2

53.6

92.5

II
April 10
$19: 32$

19.8

31.1

36.3

37.7

38.2

39.4

39.7

52.6

90.2

$\begin{array}{cc}\begin{array}{c}\text { III } \\ \text { April 10 } \\ 23: 47\end{array} & \begin{array}{c}\text { IV } \\ \text { April 11 } \\ \text { 03:08 }\end{array} \\ 19.7 & 44.8 \\ 30.5 & 55.9 \\ 34.8 & 61.0 \\ 35.9 & 62.5 \\ 37.2 & 62.9 \\ 37.2 & 64.0 \\ 38.1 & 64.5 \\ 50.2 & 77.0 \\ 89.1 & 115.4\end{array}$

The apparent $\overline{\mathrm{S}}-\overline{\mathrm{P}}$ interval at Old Woman Springs, as determined from several smaller shocks of the group, varies from about 7 to about 8 seconds. There is some uncertainty in identifying $\overline{\mathrm{S}}$ on the vertical-component seismograms, and the constancy of the time difference between the portable station and Riverside indicates that these shocks, at least, came from closely neighboring hypocenters.

The portable seismometer was operated near Cave Mountain, at $35^{\circ} 05^{\prime} .3 \mathrm{~N}$, $116^{\circ} 21^{\prime} .4$ W, by Mr. S. T. Martner and Mr. F. E. Lehner on the night of April 
14-15. One shock was large enough to be clearly recorded at the permanent stations. The times were:

\begin{tabular}{|c|c|}
\hline \multirow{2}{*}{ Cave Mountain } & April 14 \\
\hline & $23: 50: 55.2$ \\
\hline Riverside...... & $51: 12.1$ \\
\hline Mount Wilson.. & 16.6 \\
\hline Pasadena....... & 18.0 \\
\hline Boulder City... & 19.5 \\
\hline Haiwee.......... & 19.0 \\
\hline Palomar........ & 18.5 \\
\hline Tinemaha..... & 32.1 \\
\hline Tucson........ & 70.4 \\
\hline
\end{tabular}

$\overline{\mathrm{S}}-\overline{\mathrm{P}}$ at the Cave Mountain station for this shock is approximately 2.4 seconds. For other smaller shocks recorded there it ranges upward to about 3 seconds.

The portable seismometer was operated at a point here referred to as the Cady station, west of the Cady Mountains and near the Tankersley and Dorrance ranches, at $34^{\circ} 52: 9 \mathrm{~N}, 116^{\circ} 36.8 \mathrm{~W}$, by Mr. Lehner and Mr. Gilman, on the night of May 1-2. Eight or more small near-by earthquakes were recorded, several showing apparent $\overline{\mathrm{S}}-\overline{\mathrm{P}}$ intervals of from 1.0 to 1.5 seconds. Only one was recorded at the permanent stations. Readings are as follows:

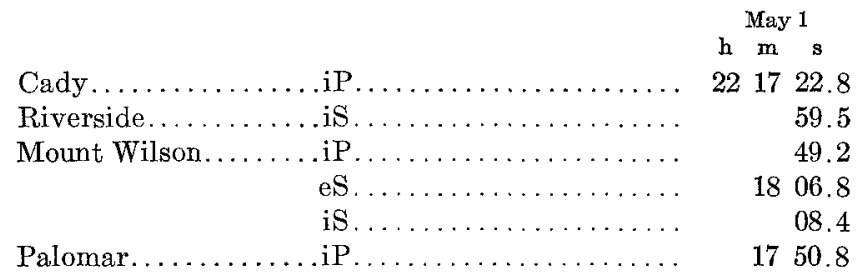

Other aftershocks as well as those here listed show a remarkably constant time difference between arrivals of first motion at Tinemaha and Haiweeclose to 13.0 seconds. The difference in distances divided by this figure gives the low velocity of about $7.8 \mathrm{~km} / \mathrm{sec}$. It is possible that arrival at Tinemaha is delayed by structures related to the root of the Sierra Nevada.

The shocks were recorded at Old Woman Springs uniformly 11 seconds earlier than at Riverside. Differences between other pairs of stations are less constant. It is especially noteworthy that the first motion at Haiwee ranges from 6.1 to 8.3 seconds later than at Riverside. Comparing data for numerous other after shocks, it appears that there are two principal groups, for one of which (group A) readings agree closely with the main shock, while the other (group B), with earlier arrivals at Riverside and Palomar, fits better to an epicenter to the south, in the CadyMountains about $34^{\circ} 56^{\prime} \mathrm{N}, 116^{\circ} 31^{\prime}$ W. This applies to shocks I, II, and IV recorded at Old Woman Springs; shock 
III is of group A. For all shocks of group B the first recorded motion at Riverside is more than one second ear.ier than that calculated with epicenter and origin time suiting the other stations. This may be accounted for by a shallower depth, so that the first motion at Riverside in these shocks is Py and not Pn. The first motion for these can be seen on the seismograms to be relatively smaller and of longer period than that for shocks of group A.

The relative position of the group A and group B epicenters is more reliable than the location of either, since both may be affected by error in the assumed structures. The data suggest an active fault surface dipping northward.

None of the recorded times indicate distribution of epicenters in the direction of the strike of the Manix fault.

Old Woman Springs is distant $63.5 \mathrm{~km}$. from the group A epicenter. It is assumed that the first motion of the main shock arrived there 10.8 seconds earlier than at Riverside (as in shock III), or at $07: 58: 16.2$. With the average depth of 18 kilometers found for southern California shocks, and a velocity of $\overline{\mathrm{P}}$ of $5.577 \mathrm{~km} / \mathrm{sec}$, the travel time should be 11.8 seconds, giving an origin time at $07: 58: 04.4$. This is 0.8 second later than that found in the least-squares solution; it suggests that the constant term in the equation for the travel time of Pn should be less than 7.0 as assumed.

The Cave Mountain station is distant $20.8 \mathrm{~km}$. from the group A epicenter. With a depth of $18 \mathrm{~km}$., this should have a travel time of 5.0 seconds, giving an origin time for this shock of $23: 55: 50.2$. The same method and assumption as used for the main shock would give an origin time of $23: 55: 49.0$. The difference is in the same direction as that found from the Old Woman Springs times.

The $\overline{\mathrm{S}}-\overline{\mathrm{P}}$ of 2.4 seconds for this shock at Cave Mountain with the usual velocities would require a travel time of only 3.8 seconds, possible if the depth is small.

The shocks reported from the Cady station are so small that few conclusions can be drawn. The very small apparent $\overline{\mathrm{S}}-\overline{\mathrm{P}}$ interval between 1 and 1.5 seconds is commonly observed at short epicentral distances, even when there is good evidence that the shocks originated at the usual depth.

For the main shock, initial compressions were recorded at Santa Barbara, Haiwee, Tinemaha, Tucson, and Fresno; initial dilatations were recorded at Pasadena, Mount Wilson, Riverside, La Jolla, and Palomar. Some of these are slightly disturbed by the preceding teleseism; however, they are confirmed by the direction of the first motion of most of the aftershocks at the same stations. Shocks recorded at Old Woman Springs, Cave Mountain, and Cady show initial dilatations. All these are consistent with strike slip in the plane of the Manix fault, such that the north side is displaced relatively westward; they are difficult to reconcile with any large dip-slip.

The most heavily shaken area was investigated in the field by Mr. Martner and Mr. Lehner on April 14-15. The following is condensed from Mr. Martner's 
field notes. Most of the places referred to are indicated on the sketch map (fig. 1).

Yermo: Damage in general slight, principally cracked plaster, etc. Vertical crack at one corner of the postoffice building (cement tile with cement mortar). Trees were seen to sway, and a low rumble was heard.

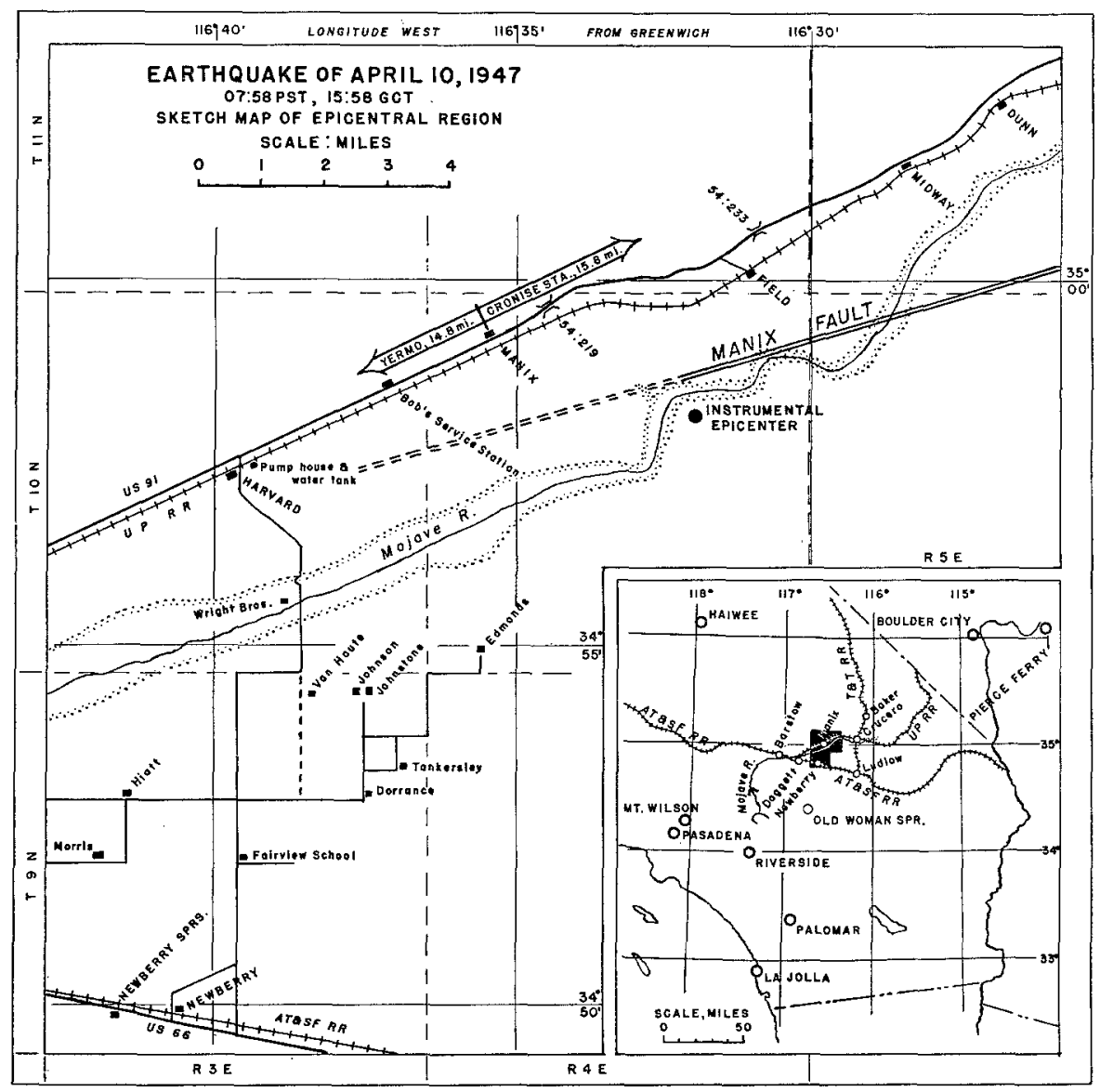

Fig. 1

Bob's Service Station. Frame construction. Brick chimney, which had good cement mortar, collapsed from the roof to the room ceiling. Shock displaced a refrigerator and a gas stove several inches. A lunch counter nineteen feet long was displaced one foot against the stools. A bed was moved about three and one-half feet. Canned and bottled goods, dishes, etc., were all thrown off shelves. Batteries of electric plant were shaken off shelves. The ground at the 
locality was dissected with many small cracks. Cement floor of the building was badly cracked. A stack of 3,000 cement building blocks was thoroughly shaken down. Cases of beer and soft drinks piled about five feet high were thrown down. Well was muddy several days after the shock. First motion from west (or parallel to the railroad).

Manix Service station. Frame construction. stuccoed. Objects generally moved from east and west walls - pictures, guns from gun racks, etc. Pictures remained in place on south wall. Piano moved south three feet.

Rafters under the galvanized iron roof appeared to have moved vertically. Concrete floor showed many cracks.

First motion felt was vertical, followed after one or two seconds by horizontal movement. A loud roaring or explosive noise was heard. Occupants were thrown to their knees and to the floor.

Much dust seen rising from hills to the southeast.

Earth fills slumped, lowering the highway a few inches, at bridges 54-219 (one mile east of Manix) and 54-223 (north of Field).

Field station, Union Pacific R.R.: Concrete building approximately 26 feet square. Many cracks produced, some 2 inches wide, especially in corners and over ends of windows and doors. Large icebox moved about 12 inches. Some glassware broken, but no pictures off walls. A low roar was heard.

Much dust seen rising from hills to the south, and continued to rise during aftershocks. Noise from shocks seemed to come from southeast.

Mr. Royse, section foreman living at Field, went into the hills to the south and, besides finding displaced rocks, saw many landslides. He was near Harvard on a handcar at the time of the main shock. The car moved noticeably but remained on the track. Power lines were set into rotary motion like a child's skipping rope. The Mojave River increased in visible flow just after the main shock. However, on April 13, Mr. Royse found the riverbed south of Field damp, with no surface flow. Walking upstream, within a short distance west he met water coming downstream. The river was not dry during the following days.

It was necessary to regrade the railroad in many places, but there were no bent rails.

Cronise: Combination gas station and café. Adobe construction, plastered inside. Plaster showed cracks. Washroom annex had a few cracks between bricks, and some bricks displaced about one inch.

Vertical vent pipe was seen in whipping motion during shock. Some articles fell off well-filled shelves. At a locality about one mile northwest, goods piled on shelves were generally thrown off.

Paymaster Mine: It was reported at second hand that at this locality ( $35^{\circ}$ $11.5 \mathrm{~N}, 115^{\circ} 53.5 \mathrm{~W}$ ) two miners on a hilltop heard a rumble and about two seconds later felt the shock. 
Afton, in Afton Canyon, is the next station on the railroad easterly from Dunn. There were twenty-five or thirty slides from steep cuts on the west side of the railroad near Afton. Newspaper reports that a trestle in Afton Canyon had settled seem to have been unfounded; however, there was much sliding and lurching on embankments, and extensive repairs were made necessary.

The remaining localities are in the area north from Newberry.

Newberry Springs store: A few cans off well-stocked shelves; no other damage.

Hiatt house: Mrs. E. F. Hiatt was out of doors; she felt a first motion $\mathrm{E}-\mathrm{W}$, and about two seconds later a motion N-S. She held to the fence to keep from falling. Pipe connections in windmill were broken. Two tanks were set one on top of the other; the top tank was tipped over southward. A bookcase and an icebox were overturned. Well is pumping less water and is muddied.

Johnstone house: Constructed of cement tiles. A few cracks in interior plaster. Large crack developed round outside between foundation and ground.

Johnson house: adobe, half underground. No mortar used in construction. Adobe cracked round door, and a few bricks were knocked off the top of the house. First motion very sharp, seemed N-S. Mr. P. B. Johnson, who was indoors, could not stand up. Gas stove was moved one foot northward; icebox out of doors was overturned southward. Piano apparently not moved, but a radio on it fell to the floor. Well became muddy. Water slopped out of tank.

Dorrance house: One-story adobe. Many cracks, but no bricks fell. Two adobe chimneys cracked but still stood. First motion from west, with later rotary motion. Water slopped out of reservoir. Many cans off shelves and many glass jars broken.

Tankersley house: One-story adobe with an adobe annex. Parts of north and west wall of main structure collapsed; all walls of the annex completely shaken down. Occupants barely escaped injury. Some interior walls down. Roof apparently undamaged. First motion appeared vertical. Nothing fell off shelves in the cellar. Reservoir dug in the ground did not spill water, but a slightly raised tank did. Well was muddied. A two-inch water line was torn from the water tank.

Van Haute house: Built at different times. North half frame with shingle covering and later rock facing with lime mortar; south half stone with cement mortar and plastered inside. On north section mortar was cracked at almost every joint. South half showed only a few cracks. Some rocks fell from under a gable on the west wall of the north section. Mr. Van Haute, who was out of doors, reported that the first motion seemed vertical followed by a heavy N-S motion. A reservoir twenty feet square was full at the time, and lost about two feet of water spilled over the north and south walls. Trees were seen to whip in all directions. No pipelines were broken, and the well was unaffected. Gas stove and sink were moved. All the dishes were thrown out of an open cabinet. 
Wright ranch: Ground water only about six feet below surface. House of railroad ties set vertically, stuccoed inside and outside. One wall badly cracked, settled about one-half inch; a few other cracks in house. Frame water-tank tower showed many cracks in exterior stucco, and its west wall showed a large bulge. Water pipes developed leaks but no breaks. Cement bottom and sides of swimming pool cracked.

Mojave River, south of Wright ranch: Numerous cracks, probably due to lurching, on both sides of the stream channel, the largest about three inches wide. South of the stream, on the terrace a few feet above the present channel, water issued from cracks. Water in the river rose two to three inches after the main shock.

Fault-trace phenomena were found along the Manix fault on April 20 by Mr. S. T. Martner, Mr. M. E. Denson, and Mr. B. F. Howell. These have been studied further and will be described in a later communication.

Acknowledgment for many courtesies and useful information is due to $\mathrm{Mr}$. and Mrs. Royse, at Field, and to Mr. and Mrs. Pero at Bob's Service Station.

\section{StTMMARY}

Instrumental epicenter and origin time for the Manix earthquake are $34^{\circ} 58^{\prime} \mathrm{N}$, $116^{\circ} 32^{\prime}$ W., $07: 58: 04$ P.S.T. (15:58:04 G.C.T.), April 10, 1947. The probable error of location does not exceed a few kilometers. Certain aftershocks originated south of the main shock. Initial recorded compressions and dilatations are consistent with left-hand strike-slip on a previously identified fault which trends about $\mathrm{N} 70^{\circ} \mathrm{E}$. Trace phenomena, to be reported later, were produced. Other effects, including damage, in the heavily shaken area are described.

Gutenberg, B.

\section{REFERENCES}

1932. "Travel Times at Small Distances, and Wave Velocities in Southern California," Gerlands Beitr. z. Geophys., Vol. 35, pp. 6-50.

Buwalda, John P.

1914. "Pleistocene Beds at Manix in the Eastern Mohave Desert Region," Univ. Calif. Publ., Bull. Dept. Geol., Vol. 7, pp. 443-464, 3 pls.

California Institute of Technology,

Pasadena, California

(Balch Graduate School of the Geological Sciences, Contribution no. 411). 